GASIMOVA F.I., KHANISHOVA M.A., TAGIYEVA K.R., AZIZOV I.V.凶

Institute of Molecular Biology and Biotechnology Azerbaijan National Akademy of Sciences, Azerbaijan, AZ 1073, Baku, Matbuat Avenue, 2A, e-mail: fazilay@yahoo.com

凶ibrahim.azizov47@gmail.com, 994506855093

\title{
THE EFFECT OF VARIOUS NaCI CONCENTRATIONS ON MORPHOPHYSIOLOGICAL PROPERTIES OF BREAD WHEAT SPROUTS (TRITICUM AESTIVUM L.)
}

Aim. The effects of various $\mathrm{NaCl}$ concentrations on germination energy, germination percentage of seeds and morpho-physiological indices of seedlings have been determined in bread wheat (Triticum aestivum L.) varieties. Methods. Wheat seeds were germinated at $0,100,150,200 \mathrm{mM}$ concentrations of $\mathrm{NaCl}$ using the roll method. Rezults. The delay of the growth of seedlings and root system was observed with increasing salt concentrations in all samples. The effect of various salt concentrations on separate varieties was diifferent. Conclusions. The highest indices of the development of coleoptiles and root system and the highest amount of chlorophyll were detected at 150 and $200 \mathrm{mM}$ concentrations of $\mathrm{NaCl}$ in the Mirbashir-128 variety. The Bezostaya and Nurlu-99 varieties manifested medium tolerance, while the Sheki-1 variety was relatively less tolerant.

Keywords: $\mathrm{NaCl}$, wheat varieties, germination energy, germination percentage, chlorophyll.

Soil salinization is one of the main stress factors limiting plant growth, development and productivity. In addition to natural salinization, careless irrigation of agricultural plants also causes a secondary salinization [1]. Salinity is known to form high osmotic potential and limits the water absorption by seeds, and $\mathrm{Na}^{+}$and $\mathrm{Cl}^{-}$ions accumulated in developing seeds have a toxic effect. It leads to the violation of enzymatic processes of carbohydrate and protein synthesis in seeds. After the root system formation the rate of the water uptake by plant roots decreases and penetration of $\mathrm{Na}^{+}$and $\mathrm{Cl}^{-}$ions into plant cell weakens cell ultrastructure and chloroplast photosystem. The structure of the plasmatic membrane and the function of the ion pumps are disturbed under the influence of $\mathrm{Na}^{+}$ions. In many cases this results in the imbalance between $\mathrm{Na}^{+}$and $\mathrm{Cl}^{-}$ions in cytosol [2-6].

Defense mechanisms against environmental stress factors were formed in living organisms during the evolution process and plant tolerance to salinity occurred due to various defense mechanisms.
Some soluble substances - osmolites are synthesized in cells in order to protect plants from stress. These mechanisms provide plant tolerance against salt ions and further realize reparation of cell damage [7].

High salt concentrations decrease solubility of small amounts of food elements obstructing their access to plants and destructively affect normal physiological processes, increasing the formation of reactive oxygen species (ROS) [8]. Toxic effects of $\mathrm{Na}+$ and $\mathrm{Cl}-$ ions on intracellular mechanisms of regulation processes and their relation to pigments, especially in the view of the initial molecular damage caused by stressors of this type have not been studied sufficiently [9].

The main purpose of the presented research was to evaluate salt tolerance of bread wheat genotypes according to the morphometric indices in the germination stage and to establish changes in leaf water regime, the amount of photosynthetic pigments, and changes in PS II activities of chloroplasts.

\section{Materials and methods}

Highly productive bread wheat (Triticum aestivum L.) varieties (Mirbashir-128, Sheki-1, Bezostaya, Nurlu-99) were used as the objects of the study.

Seeds were germinated using the roll method for studying the effect of salt on morphophysiological indices of wheat seedlings grown at various salt concentrations $[5,6]$. Wheat genotypes were screened for salt tolerance using $\mathrm{NaCl}$ solutions of various concentrations. For this purpose seeds of each sample were germinated on the wet filter paper at $20-22^{0} \mathrm{C}$ temperature, for 3 days in the dark, and for 11 days at the photoperiod of 12 hours light/12 hours dark. Germination ability of wheat embyo under salt stress, average length of roots and shoots were measured for 14 days and tolerance of the varieties were evaluated according to morphometric parameters. Germination ability germination energy and germination percentage

\footnotetext{
${ }^{\circ}$ GASIMOVA F.I., KHANISHOVA M.A., TAGIYEVA K.R., AZIZOV I.V.
} 
were determined after 3 and 7 days of germination, respectively, for each variant of wheat genotypes [10]. Salt effects on physiological parameters were studied in 14-day-old leaves.

Relative water content (RWC) of leaves was determined according to Tambussi et al. [11]. Water parameters were estimated according to the formula:

$\mathrm{RWC}=100 \%(\mathrm{FW}-\mathrm{DW}) /(\mathrm{TW}-\mathrm{DW})$

where:

FW - fresh weight

TW - turgor weight

DW - dry weight

Chlorophyll was extracted from leaves by $96 \%$ ethanol, and chlorophyll a, chlorophyll b and carotenoids were measured spectrophotometrically at $665 \mathrm{~nm}, 649 \mathrm{~nm}$ and $440 \mathrm{~nm}$, respectively. Amounts of pigments were determined according to the method of Wintermans [12] (I.F. Wintermans A. De. Mots, 1965).

The concentrations of pigments were estimated according to the absorption at $665 \mathrm{~nm}$, $649 \mathrm{~nm}$ and $440 \mathrm{~nm}$ using the following formulae:

$\mathrm{C}_{\mathrm{a}}=13.70 \cdot \mathrm{A}_{665}-5.76 \cdot \mathrm{A}_{649}$;

$\mathrm{C}_{\mathrm{b}}=25.80 \cdot \mathrm{A}_{649}-7.6 \cdot \mathrm{A}_{665}$;

$\mathrm{C}_{\mathrm{a}+\mathrm{b}}=6.10 \cdot \mathrm{A}_{665}+20.04 \cdot \mathrm{A}_{649}=25.1 \cdot \mathrm{A}_{654}$;

$\mathrm{C}_{\mathrm{car}}=4.695 \cdot \mathrm{A}_{440,5}-0.268\left(\mathrm{C}_{\mathrm{a}+\mathrm{b}}\right)$;

where:

$\mathrm{C}_{\mathrm{a}}, \mathrm{C}_{\mathrm{b}}, \mathrm{C}_{\mathrm{car}}$ - pigment concentration ( $\left.\mathrm{mg} / \mathrm{ml}\right)$;

$\mathrm{A}_{665}, \mathrm{~A}_{649}, \mathrm{~A}_{440}$ - absorption

Fluorescent indices of leaves were measured using MINI-PAM (photosynthesis yield analizer, Germany) device. Using the formulae $F_{v}=F_{m}-F_{0}$ and $F_{v} / F_{m}$ the efficiency of photochemical conversions in PS II was determined (13).

$\mathrm{F}_{0}$ - fluorescence of dark-adapted leaf;

$\mathrm{F}_{\mathrm{m}}$ - fluorescence of light-saturated leaves;

$\mathrm{F}_{\mathrm{v}}=\mathrm{F}_{\mathrm{m}}-\mathrm{F}_{0}-$ variable fluorescence;

$F_{v} / F_{m}-$ the efficiency of photochemical conversions in PS II

Data analysis and statistical analysis was conducted in Microsoft Excel. Statistical analysis was performed with the aid of the Statgraphics Plus 5.1 statistical package. The means of values were compared by Duncan's multiple range test $(\mathrm{p}=0.05)$.

\section{Results and discussion}

The study of the effect of various $\mathrm{NaCl}$ concentrations on the germination ability of wheat genotypes showed that stress caused a decrease in the germination energy of embryos in 3-day-old wheat seedlings and a less decrease compared with other varieties was observed in the Mirbashir-128 variety.

Thus, as seen in the table 1 , under chloride salinity germination energy of bread wheat genotypes in control variants decreased from $93 \%$ to 63 $\%$ and $100 \mathrm{mM}, 150 \mathrm{mM}$ and $200 \mathrm{mM}$ concentrations of $\mathrm{NaCl}$ decreased the germination energy from $80 \%$ to $60 \%$, from $60 \%$ to $53 \%$ and from $53 \%$ to $27 \%$, respectively. But, all varieties in every variant have maximum germination (Table 1). Effects of various $\mathrm{NaCl}$ concentrations on the germination of bread wheat genotypes energy. Only in the Sheki-1 variety a relatively small decrease $(27 \%)$ in the germination energy was obseerved at $200 \mathrm{mM} \mathrm{NaCl}$.

A general development of the root system and a close relation to some traits of plants indicate the importance of these parameters. The change in linear parameters of the growth processes expresses salt tolerance of varieties more precisely, compared with germination indices of seeds, which is related to the general tolerance of the plant. The delay in plant growth under unfavorable conditions, which occurs due to suppression of cell pressure and tension, can be considered as the defense reaction of the plant. Tolerant forms adapt faster to stress and recover their development (6). The effect of various salt concentrations on the growth of shoots and roots shows that first the root system and then above-ground organs of the plant are damaged. According to some authors it occurs due to the different tolerance of separate plant organs (14) .

Fig. $1(\mathrm{a}, \mathrm{b})$ shows dependence between bread wheat genotype indices (length of roots and shoots) and salt concentration for 14 days. The growth dynamics of roots and shoots during 14 days showed that dynamics of the development of all wheat genotypes was normal in the germination phase and the germination rate of shoots decreased with increasing salt concentration compared with control. The growth of shoots and roots of all samples delayed with increasing salt concentration. At the same time the influence of various salt concentrations on separate varieties was different. Thus, at $150 \mathrm{mmol}$ and $200 \mathrm{mmol}$ concentrations of $\mathrm{NaCl}$ the highest growth indices of coleoptiles and root system was observed in the Mirbashir-128 variety. Moderate tolerance was detected in Nurlu-99 and Sheki-1 showed relatively weak tolerance. 
Gasimova F.I., Khanishova M.A., Tagiyeva K.R., Azizov I.V.

Table 1. Effects of various $\mathrm{NaCl}$ concentrations on the germination of bread wheat genotypes

\begin{tabular}{|c|c|c|c|c|c|c|c|c|}
\hline \multirow{8}{*}{ Varieties } & \multicolumn{9}{|c|}{$\mathrm{NaCl}, \mathrm{mM}$} & \multicolumn{4}{c|}{ NaCl, mM } \\
\cline { 2 - 9 } & Control & 100 & 150 & 200 & Control & 100 & 150 & 200 \\
\hline & \multicolumn{3}{|c|}{ Germination energy, \% } & \multicolumn{3}{c|}{ Germination percentage, \% } \\
\hline $\begin{array}{c}\text { Mirbashir- } \\
128\end{array}$ & 93 & 80 & 60 & 53 & 100 & 100 & 93 & 80 \\
\hline Sheki-1 & 67 & 60 & 53 & 27 & 100 & 93 & 87 & 60 \\
\hline Bezostaya & 73 & 73 & 60 & 27 & 100 & 87 & 87 & 67 \\
\hline Nurlu-99 & 87 & 80 & 60 & 53 & 100 & 100 & 73 & 67 \\
\hline
\end{tabular}

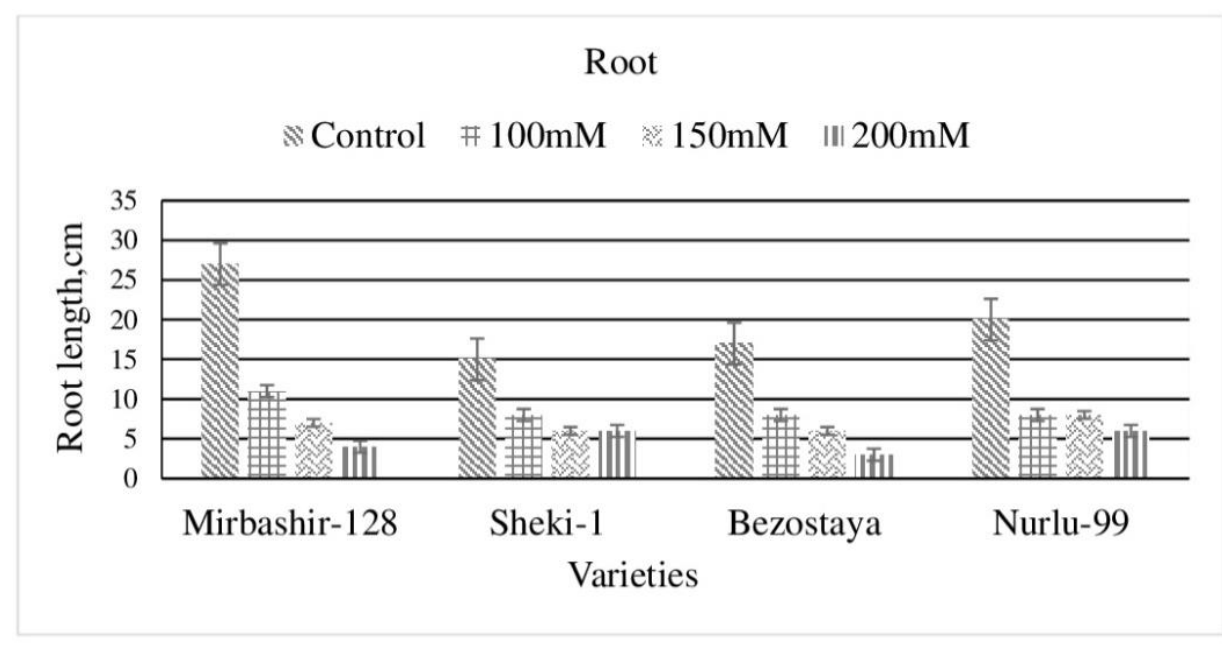

a

Shoot

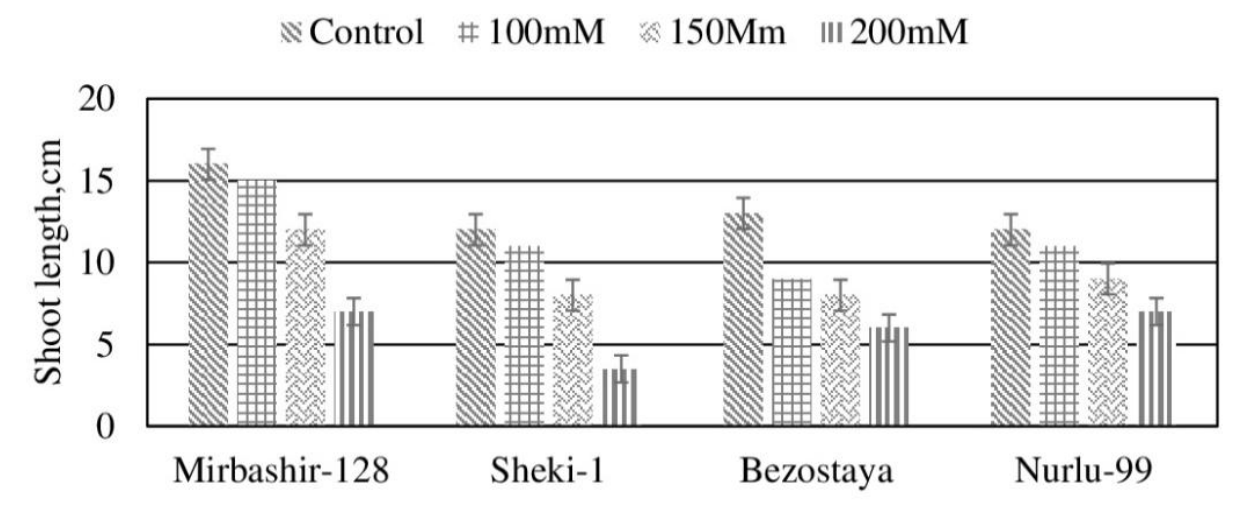

Varieties

b

Fig. 1. (a, b). Indices (the length of roots and shoots, for 14 days) of bread wheat genotypes grown at various salt concentrations. Each bar represents mean $\pm \mathrm{sd}$ (standart deviation) for average of $\mathrm{n}=3$ independent experiments; $\mathrm{P}=0.05$.

RWC was studied in 14-day-old shoots of bread wheat genotypes grown at various salt concentrations (fig. 2). As seen in the figure in leaves of 14 day-old shoots RWC significantly decreased with increasing salt concentrations. But there was no pronounced difference between dynamics of changes in RWC depending on salt concentrations in the studied wheat genotypes.

However, RWC values for the Mirbashir-128 variety were higher (by $18 \%$ ) compared with Sheki-1 under high salt concentration. The obtained 
results show that Mirbashir-128 is more tolerant to salt compared with other varieties.

Changes in plant leaf pigments provide an important information on physiological status and adaptation of the plant to the changing environment [15]. The purpose of our research was the evaluation of the effect of various $\mathrm{NaCl}$ concentrations on photosynthetic pigments in wheat leaves as the indicator of the degree of stress factor influence on the plant growth. An increase in salt concentration causes the disturbance in ion homeostasis in plants at the cell and whole plant level. In its turn it leads to various toxic effects manifested as cytoplasmic biopolymer damages. The effect of salt on the amount of green pigments in 14-day-old leaves showed that the changes in photosynthetic pigments are correlated with a decrease in RWC. Total amount of chlorophyll decreased in all varieties with increasing salt concentrations. But this parameter was higher for the Mirbashir-128 genotype compared with others (Table 2).

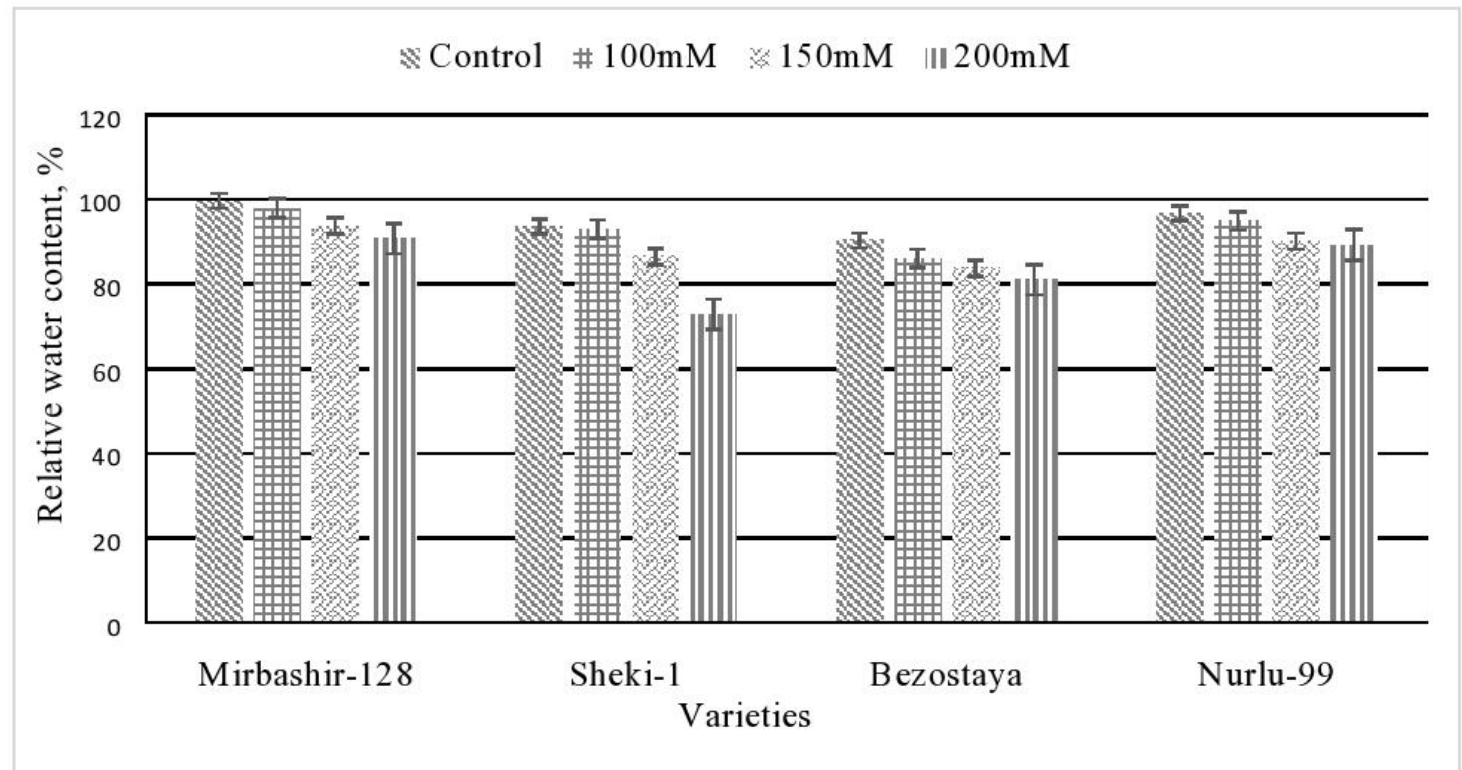

Fig. 2. RWC in 14-day-old leaves of bread wheat varieties grown under various $\mathrm{NaCl}$ concentrations . Each bar represents mean $\pm \mathrm{sd}$ (standart deviation) for average of $\mathrm{n}=3$ independent experiments; $\mathrm{P}=0.05$.

Table 2. The influence of various $\mathrm{NaCl}$ concentrations on the amounts of chlorophyll and carotenoids $(\mathrm{mg} / \mathrm{g})$, and the energy conversion efficiency of PS II (Y).

\begin{tabular}{|c|c|c|c|c|c|c|c|}
\hline No & Varieties & $\mathrm{NaCl}, \mathrm{mM}$ & $\mathbf{C}_{\mathrm{a}}$ & $\mathbf{C}_{\mathrm{b}}$ & $\mathrm{C}_{\mathrm{a} / \mathrm{b}}$ & $\mathbf{C}_{\mathrm{kar}}$ & $\mathbf{Y}$ \\
\hline \multirow{4}{*}{1} & \multirow{4}{*}{ Mirbashir-128 } & 0 & 16.0 & 4.8 & 3.3 & 3.3 & 0.79 \\
\hline & & 100 & 10.9 & 3.9 & 2.8 & 3.2 & 0.74 \\
\hline & & 150 & 9.4 & 3.8 & 2.5 & 2.1 & 0.79 \\
\hline & & 200 & 5.0 & 2.0 & 2.5 & 1.2 & 0.6 \\
\hline \multirow{4}{*}{2} & \multirow{4}{*}{ Sheki-1 } & 0 & 9.5 & 3.7 & 2.5 & 2.6 & 0.78 \\
\hline & & 100 & 7.2 & 2.3 & 3.1 & 1.7 & 0.79 \\
\hline & & 150 & 6.3 & 2.2 & 2,8 & 1.6 & 0.71 \\
\hline & & 200 & 4.7 & 1.7 & 2.7 & 1.5 & 0.70 \\
\hline \multirow{4}{*}{3} & \multirow{4}{*}{ Bezostaya } & 0 & 11.0 & 4.3 & 2.5 & 2.9 & 0.78 \\
\hline & & 100 & 11.0 & 4.3 & 2.5 & 2.9 & 0.79 \\
\hline & & 150 & 5.4 & 1.7 & 3.2 & 1.3 & 0.8 \\
\hline & & 200 & 1.7 & 0.7 & 2.4 & 0.5 & 0.7 \\
\hline \multirow{4}{*}{4} & \multirow{4}{*}{ Nurlu-99 } & 0 & 8.9 & 3.2 & 2.8 & 2.0 & 0.81 \\
\hline & & 100 & 7.6 & 2.6 & 2.9 & 1.6 & 0.79 \\
\hline & & 150 & 7.1 & 2.5 & 2.8 & 1,7 & 0.79 \\
\hline & & 200 & 7.0 & 2.2 & 3.1 & 1,6 & 0.77 \\
\hline
\end{tabular}


As seen in the Table 2, an increase occurred in the chlorophyll $\mathrm{a} / \mathrm{b}$ ratio and carotenoid amounts under the $\mathrm{NaCl}$ influence. According to some authors, amounts of chlorophyll $b$ decreased more markedly in leaves of various wheat genotypes exposed to salt and drought stress [16]. Such a pattern we observed only in Nurlu-99. The efficiency of the photochemical conversion of the PS II energy decreased with increasing salt concentrations. Some authors indicate the decrease of the root system function in plants exposed to salt stress. They assumed a more important role of toxic effects of ions [17]. Our results confirmed that salt stress effects are initially expressed themselves in changes occurring in seeds.

\section{Conclusions}

Thus, the research performed showed that salt stress negatively affects germination ability, RWC of leaves, amounts of photosynthetic pigments and the PS II activity of wheat genotypes. The obtained results confirmed that the tolerance to extreme stress conditions is a consequence of complex physiological adaptive responses of plants.

This work was supported by a grant (EIF-KEPTL-2-2015-1(25)-56/35/3) of the Science Development Foundation under the President of the Republic of Azerbaijan.

\section{References}

1. Flovers T.J. Improving crop salt tolerance. J. Exp. Bot. 2004. Vol. 55. P. 307-319.

2. Bouaziz A., Hick D. Consumption of wheat seed reserves during germination and early growth as affected by soil water potential. Plant soil. 1990. Vol. 128. P. 161-165.

3. Ramagopal S. Inhibition of seed germination by salt and its subsequent effect on embryonic protein synthesis in Barley. J. Plant Physiol. 1990. 136. P. 621-625.

4. Shevyakova N.I. Metabolism and physiological role of proline in plants under water and salt stress. Plant Physiol. 1982. Vol. 30, Issue 4. P. 743-751.

5. Шихмурадов А.З. Устойчивость дирлоидных видов пшеницы к повышенному содержанию $\mathrm{NaCl}$ Юг России: экология, развитие. 2011. Т. 1. С. 40-43.

6. Shykhmuradov A.Z. Stability of diploid wheat species to increased $\mathrm{NaCl}$ content. South of Russia: ecology, development. 2011. V. 1. P. 40-43.

7. Белозерова А.А., Боме Н.А. Изучение реакции яровой пшеницы на засоление по изменчивости морфометрических параметров проростков. Фундаментальные исследования. 2014. Т. 12, 2. С. 3-30.

8. Belozerova A.A., Bome N.A The study of the response of spring wheat to salinity by the variability of the morphometric parameters of seedlings. Fundamental research. 2014. Vol. 12, 2. P. 3-30.

9. Kuznetsov V.V., Chidirov B., Roshunkin B.V., Borisova N.N. General systems of the tolerance of cotton to salinity and high temperature: factors and hypotheses. Plant Physiology. 1990. Vol. 37, Issue 5. P. 987-996.

10. Yadav S., Irfan M., Ahmad A., Hayat. Causes of salinity and plant manifestations to salt stress: a review. Environ Biol. 2011. Vol. 32 (5). P. 667-685.

11. Amirjani M.R. Effekt of salinity stress on growth, sugar content, pigments and enzyme activity of rice. Int. botany. 2011. Vol. 7. P. 73-81.

12. Алиев Р.Т., Аббасов М.А., Рагимли В.Р. Стресс и адаптация растений. 2014. 120 с.

13. Alyev R.T., Abbasov M.A., Rahymly V.R. Stress and adaptation of plants. 2014. 120 p.

14. Tambussi E.A., Nogues S., Araus L. Ear of durum wheat under water stress: water relations and photosynthetic metabolism. Planta. 2005. P. 1-25.

15. Гавриленко В.Ф., Жигалова Т.В. Большой практикум по фотосинтезу. М., 2003. С. 46-55.

16. Havrylenko V.F., Zyhyhalova T.V. A large practicum on photosynthesis. M., 2003. P. 46-55.

17. Maxwell K., Jonson G. Chlorophyll fluorescence - a practical guide. Journal of experimental botany. 2000. Vol. 5, No. 345. P. 659-665.

18. Kuznetsov V.V., Shevyakova N.I. Polyamines and plant adaptation to saline environment. Desert plants. Springer - Verlag, 2010. P. 261-298.

19. Gang I., Shuwen W., Jian Z., Zhiyong Y., Qina P. Leaf chlorophyll fluorescence, hyperspectral reflectance, pigments content, malondialdehyde and proline accumulation responses of castor bean (Ricinus communis L.) seedlings to salt stress levels. Ind Crops Prod. 2010. Vol. 31. P. 13-19.

20. Атоев М.Х., Эргашев А., Абдуллаев А., Джумаев Б.Б. Влияние засоления и почвенной засухи на содержание фотосинтетических пигментов в листьях различных видов и сортов пшеницы. Изв. Отд. Биол. и Мед. АН РТ. 2011 . № 3. C. $13-20$.

21. Atoev M.Kh., Эrhashev A., Abdullaev A., Dzumaev B.B. The effect of salinization and soil drought on the content of photosynthetic pigments in leaves of various species and varieties of wheat. Proceeds of the Department of Biology and Medicine. AN RT. 2011. № 3. P. 13-20.

22. Wang Wen-Yuan, Yan Xiao-Feng, Jiang Ying, Qu Bo, Xu Yu - Feng Effects of salt stress on water content and photosynthetic characteristics in iris lactera Var. Chinessis seedlings. Middle - East Journal of scientific research. 2012. Vol. 12 (1). P. 70-74. 
ГАСИМОВА Ф.І., ХАНИШОВА М.А., ТАГІЕВА К.Р., АЗІЗОВ І.В.

Інститут молекулярної біології і біотехнологій Наџіональної академії наук Азербайджану, Азербайджан, AZ 1073, м Баку, проспект Матбуат, 2A, e-mail: fazilay@yahoo.com, ibrahim.azizov47@gmail.com

\section{ВПЛИВ РІЗНИХ КОНЦЕНТРАЦІЙ NaCІ НА МОРФОФІЗІОЛОГІЧНІ ВЛАСТИВОСТІ ПРОРОСТКІВ} М'ЯКОÏ ПШЕНИЦI (TRITICUM AESTIVUM L.)

Mema. Досліджено вплив різних концентрацій $\mathrm{NaCl}$ на енергію проростання, відсоток проростання насіння і морфофізіологічні показники проростків у генотипів м'якої пшениці (Triticum aestivum L.). Memoди. Насіння пшениці пророщували за $0,100,150,200$ мМ концентрацій $\mathrm{NaCl} 3$ використанням рулонного методу. Результати. Зі збільшенням концентрації хлористого натрію спостерігалася затримка росту проростків і кореневої системи у всіх зразках. Різні концентрації солі на окремі сорти впливали по-різному. Висновки. Вищі показники розвитку проростків і кореневої системи і найбільшу кількість хлорофілу було виявлено при 150 i 200 мМ концентраціях $\mathrm{NaCl}$ у сорту Мірбашір-128. Сорти Безостая і Нурли-99 проявляли середню толерантність, у той час як сорт Шекі-1 був менш толерантним.

Ключові слова: $\mathrm{NaCl}$, сорти пшениці, енергія проростання, відсоток проростання, хлорофіл.

ГАСЫМОВА Ф.И., ХАНЫШОВА М.А., ТАГИЕВА К.Р., АЗИЗОВ И.В.

Институт молекулярной биологии и биотехнологии Национальной академии наук Азербайджана, Азербайджан, AZ 1073, г. Баку, проспект Mатбуат, 2A, e-mail: fazilay@yahoo.com, ibrahim.azizov47@gmail.com

ВЛИЯНИЕ РАЗЛИЧНЫХ КОНЦЕНТРАЦИЙ NaСІ НА МОРФОФИЗИОЛОГИЧЕСКИЕ СВОЙСТВА ПРОРОСТКОВ МЯГКОЙ ПШЕНИЦЫ (TRITICUM AESTIVUM L.)

Цель. Исследовано влияние различных концентраций $\mathrm{NaCl}$ на энергию прорастания, процент прорастания семян и морфофизиологические показатели проростков у генотипов мягкой пшеницы (Triticum aestivum L.). Memodb. Семена пшеницы проращивали при 0, 100, 150, 200 мМ концентрациях $\mathrm{NaCl}$ с использованием рулонного метода. Результаты. С увеличением концентрации хлористого натрия наблюдалась задержка роста проростков и корневой системы во всех образцах. Различные концентраций соли на отдельные сорта влияли поразному. Выводы. Более высокие показатели развития проростков и корневой системы и наибольшее количество хлорофилла было обнаружено при 150 и 200 мМ концентрациях $\mathrm{NaCl}$ у сорта Мирбашир-128. Сорта Безостая и Нурлу-99 проявляли среднюю толерантность, в то время как сорт Шеки-1 был относительно менее толерантным.

Ключевые слова: $\mathrm{NaCl}$, сорта пшеницы, энергия прорастания, процент прорастания, хлорофилл. 